\title{
Amorphous Ca-phosphate precursors for Ca-carbonate biominerals mediated by Chromohalobacter marismortui
}

\author{
María Angustias Rivadeneyra ${ }^{1}$, Agustín Martín-Algarra ${ }^{2}$, Mónica Sánchez-Román ${ }^{3}$, \\ Antonio Sánchez-Navas ${ }^{3}$ and José Daniel Martín-Ramos ${ }^{3}$ \\ ${ }^{1}$ Department of Microbiology, Faculty of Pharmacy, University of Granada, Granada, Spain; ${ }^{2}$ Department of \\ Stratigraphy and Paleontology, Faculty of Sciences and IACT-CSIC, University of Granada, Granada, Spain \\ and ${ }^{3}$ Department of Mineralogy and Petrology, Faculty of Sciences and IACT-CSIC, University of Granada, \\ Granada, Spain
}

\begin{abstract}
Although diverse microbial metabolisms are known to induce the precipitation of carbonate minerals, the mechanisms involved in the bacterial mediation, in particular nucleation, are still debated. The study of aragonite precipitation by Chromohalobacter marismortui during the early stages (3-7 days) of culture experiments, and its relation to bacterial metabolic pathways, shows that: (1) carbonate nucleation occurs after precipitation of an amorphous Ca phosphate precursor phase on bacterial cell surfaces and/or embedded in bacterial films; (2) precipitation of this precursor phase results from local high concentrations of $\mathrm{PO}_{4}^{3-}$ and $\mathrm{Ca}^{2+}$ binding around bacterial cell envelopes; and (3) crystalline nanoparticles, a few hundred nanometres in diametre, form after dissolution of precursor phosphate globules, and later aggregate, allowing the accretion of aragonite bioliths.

The ISME Journal (2010) 4, 922-932; doi:10.1038/ismej.2010.17; published online 25 February 2010

Subject Category: Geomicrobiology and microbial contributions to geochemical cycles

Keywords: amorphous calcium phosphate; precursor; nanoparticles; $C$. marismortui
\end{abstract}

\section{Introduction}

Microorganisms, mainly bacteria, contribute to the precipitation of a wide variety of minerals (Ehrlich, 2002). Numerous laboratory studies and observations made in natural environments demonstrate bacterial precipitation of carbonates and phosphates (Beavon and Heatley, 1962; Morita, 1980; Vasconcelos and McKenzie, 1997; Castanier et al., 1999; Warthmann et al., 2000; van Lith et al., 2002; Wright and Wacey, 2005; Rivadeneyra et al., 1999, 2000, 2006; Sánchez-Román et al., 2007, 2009a,b). Different mechanisms have been proposed for bacterially mediated precipitation of carbonate minerals (for example, Rivadeneyra et al., 1996, 1998; van Lith et al., 2003; Sánchez-Román et al., 2007, 2008). The metabolic activity of the bacteria alters the physicochemical parameters of their surrounding habitats, allowing the precipitation of minerals (for example, Ehrlich, 2002).

Correspondence: A Martín-Algarra, Department of Stratigraphy and Paleontology, Faculty of Sciences, University of Granada, 18071 Granada, Spain.

E-mail: agustin@ugr.es

Received 9 June 2009; revised 18 January 2010; accepted 26 January 2010; published online 25 February 2010
The role of bacterial surfaces in the nucleation of certain minerals (such as some types of carbonates) has also been widely discussed, but the exact role of the bacteria in such nucleation remains unclear. Aloisi et al. (2006) considered the formation of carbonate nanoglobules to be the first step for microbial calcification of sulphate-reducing bacteria. Rivadeneyra et al. (2006) and Sánchez-Román et al. (2008) have shown that carbonate nanocrystals and nanoglobules nucleate on the surface of moderately halophilic aerobic bacterial cells. These and other studies have suggested that microbes influence nucleation and that, in general, they control the kinetics of the carbonate precipitation, producing crystal-growth features that are interpreted as morphological proxies for microbially mediated precipitation of carbonate minerals (Sánchez-Navas et al., 2009, and references therein. In addition, the morphology of the mineral precipitates has also been considered a possible indicator of ancient life in the rock record, and of extraterrestrial life in meteorites for example, Allen et al., 2000; McKay et al., 1996). Martín-Algarra and Sánchez-Navas (1995, 2000), Sánchez-Navas et al. (1998) and Sánchez-Navas and Martín-Algarra (2001) recognized the existence of amorphous precursors for bacterial precipitates in fossil (Mesozoic) open 
marine phosphate stromatolites, and proposed that their texture and composition provide useful bacterial biosignatures and information on the physicochemistry and palaeoceanography of the sedimentary environment.

Rivadeneyra et al. (2006) described for the first time the precipitation of minerals by Chromohalobacter marismortui. This bacterium is of interest because it co-precipitates carbonate and phosphate minerals in the same culture medium, as well as different carbonate minerals, according to the salinity and viscosity of the medium. In this study, we focus on the carbonate precipitation by C. marismortui at the nanometre scale, using scanning and transmission electron microscopy (SEM and TEM). Indeed, we studied the mineralogical evolution of the precipitates at different times (3-7 and 40 days). We report, for the first time, the nucleation of amorphous Ca phosphate (ACP) phases as a transient stage in the precipitation of aragonite in liquid medium by $C$. marismortui, and we discuss the relation of this microorganism with the physicochemical conditions of the culture medium.

\section{Materials and methods}

\section{Microorganism and culture medium}

The bacterium studied was $C$. marismortui American Type Culture Collection (ATCC) 17056 (=Czech Collection of Microorganisms (CCM) 3518), which was isolated from the Dead Sea, described by ElazariVolcani in 1940 as Chromobacterium marismortui, and later classified as C. marismortui (Ventosa et al., 1989). It is a Gram-negative, moderately halophilic, chemoorganotrophic and strictly aerobic bacterium that metabolizes nitrogenated organic matter (proteins, amino acids and nucleic acids) with the subsequent production of $\mathrm{CO}_{2}, \mathrm{NH}_{3}$ and $\mathrm{PO}_{4}^{3-}$.

A liquid medium of the following composition (weight/volume) was used: $1 \%$ yeast extract; $0.5 \%$ proteose peptone; $0.1 \%$ glucose; and $0.4 \%$ Ca acetate. The medium was supplemented with a balanced mixture of artificial sea salt to a final concentration of $7.5 \%(\mathrm{w} / \mathrm{v})$. The $\mathrm{pH}$ was adjusted to 7.2 with $1 \mathrm{M}$ $\mathrm{KOH}$. Using this composition, the total alkalinity or buffering capacity of the culture medium cannot be estimated because the yeast extract and proteose peptone have not an exact chemical formula.

To test the first stages of the precipitation process under SEM, we seeded C. marismortui in liquid medium in wide-mouthed bottles containing $20 \mathrm{ml}$ of culture medium into which glass cover slips had been previously placed in a vertical position. The bottles were incubated at $32{ }^{\circ} \mathrm{C}$ and cover slips were removed for study each day for a total of 7 days.

C. marismortui was also inoculated into $500-\mathrm{ml}$ Erlenmeyer flasks containing $150 \mathrm{ml}$ of culture medium and incubated at $32{ }^{\circ} \mathrm{C}$. The $\mathrm{pH}$ of the cultures was measured using a Crison $\mathrm{pH}$ metre Basic 20 (Crison Instruments SA, Barcelona, Spain).
The microbial precipitates were recovered from the medium after $3,4,6,5,7$ and 40 days of incubation, transferred to distilled water and washed free of impurities. Then, the precipitates were air-dried at $37^{\circ} \mathrm{C}$, and studied by X-ray diffraction (XRD), SEM and TEM. Sterile cultures (with and without dead cells) were also included in each experiment.

\section{XRD study}

The precipitates obtained at $3,4,5,6,7$ and 40 days of incubation were examined by powder XRD using a Philips PW 1710/00 diffractometer (Philips, Eindhoven, The Netherlands), with a graphite monochromator, automatic slit, $\mathrm{CuK} \alpha$ radiation and on-line connection with a microcomputer. Data were collected for 0.4-s integration time in $0.02^{\circ} 2 \theta$ steps at $40 \mathrm{kV}$ and $40 \mathrm{~mA}$, in a $2 \theta$ interval between $3-80^{\circ}$. Data were processed using the XPowder program for a qualitative and quantitative determination of the mineral composition (Martín, 2004). Preparation of the samples involved, in some cases, in pulverization in an agate mortar before analysis. Struvite crystals were optically identified, separated from the carbonate fraction and then independently analysed.

\section{SEM and TEM studies}

Secondary electron micrographs were made with gold-coated samples using a Zeiss DMS SEM (LEO Electron Microscopy, Oberkochen, Germany), operated at an acceleration voltage of $10-20 \mathrm{kV}$, to examine the micromorphology of the precipitates. Some selected samples were coated with carbon for energy dispersive X-ray (EDX) microanalysis. High-resolution secondary electron images were prepared with a field emission SEM LEO 1525 (LEO Electron Microscopy), under $2-3 \mathrm{kV}$ on carbon-coated samples.

The samples of bacterial precipitates taken after 3-7 days of culture were examined under TEM. The same (not pulverized) powder samples of bacterial precipitates used for XRD analysis were embedded in an epoxy resin, then sectioned by ultramicrotome following the methodology of Vali and Koster (1986) for clays, and finally carbon coated. To emphasize visualization of incipiently mineralized areas, we used unstained samples; therefore, unmineralized bacterial cell organelles could not be seen. The samples were examined using a Zeiss EM902 TEM instrument (LEO Electron Microscopy), equipped with an integrated imaging electron-energy spectrometer, operating at an acceleration voltage of $80 \mathrm{kV}$. Optimum amplitude contrast of bacterial amorphous phosphates (see below) was achieved using lens aperture of $30 \mu \mathrm{m}$, and afterward removing inelastic electrons by zero-loss filtering in the elastic scattering image mode. The analytical electron microscopy study was performed using a Philips CM20 instrument (Philips) operated at $200 \mathrm{kV}$ and equipped with an EDX model EDAX system (EDAX Inc., Mahwah, NY, USA) for microanalysis. Analytical 
electron microscopy microanalyses in scanning transmission electron microscopy mode were performed using a $5-\mathrm{nm}$ beam diametre and a scanning area of $1000 \times 20 \mathrm{~nm}$. A $\mathrm{SiK} \alpha$ peak, which is an artefact produced by the silicon detector of the instrument, systematically seems in the analytical electron microscopy spectra corresponding to samples of poorly mineralized materials prepared by ultra-micromicrotomy, such as those studied here. The Ca:P atomic proportion of the bacterial amorphous phosphate phases was determined after calibration of the $K_{\mathrm{CaP}}$ factor using a standard stoichiometric hydroxyapatite, $\mathrm{Ca}_{10}(\mathrm{OH})_{2}\left(\mathrm{PO}_{4}\right)_{6}$, following the method of Abad and Nieto (2006).

\section{Results}

Figure 1 shows the $\mathrm{pH}$ evolution in $C$. marismortui liquid-culture experiments. After a short fall at the beginning, the $\mathrm{pH}$ significantly rose from the original $\mathrm{pH} 7.2$ of the medium to 9.4, whereas changes in $\mathrm{pH}$ or precipitation were not detected in control experiments.

The XRD data indicate that the precipitates found during the first week (arrows in Figure 1) were essentially non-crystalline. Nevertheless, SEM examination indicated that protocrystalline carbonate phases precursory of aragonite started to develop after 3 days of incubation. This was confirmed by the first record of some isolated diffraction peaks within the XRD patterns. After 40 days of incubation, the precipitates were formed by aragonite and struvite, although amorphous phases were still very abundant (Figure 2a). Figure 2b presents a map illustrating the transition from the early precipitation of amorphous phases to crystalline aragonite with increasing incubation time. This map was drawn from the XRD patterns of three selected samples: two of the precipitates formed during the first week of incubation and one of the aragonite precipitate formed after 40 days of incubation.

Figures 3 and 4 reproduce SEM and TEM images of the precipitates formed during the first week of incubation. Bacterial growth on glass cover

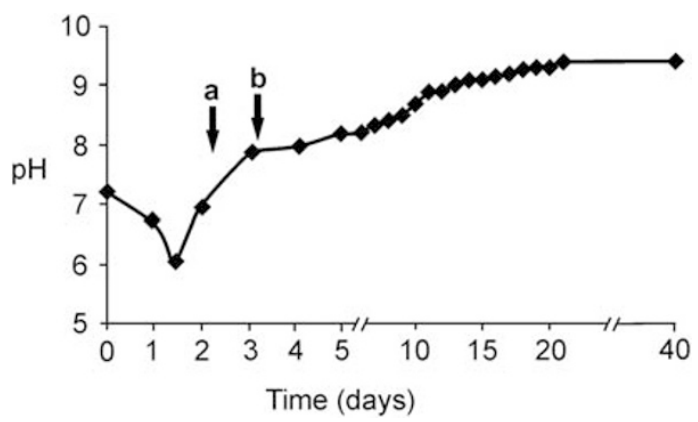

Figure 1 Evolution of $\mathrm{pH}$ in Chromohalobacter marismortui culture experiments. Arrows point to the first occurrence of amorphous Ca-phosphate (a) and of $\mathrm{CaCO} 3$ bioliths within an amorphous matrix (b). slips after 4 days of incubation was identified as aggregates of mineralized bacterial cells (Figure 3a). The bacterial organic film and the bacterial surfaces seem surrounded by globular nanoforms composed of mineral precipitates (Figures $3 \mathrm{~b}$ and $\mathrm{c}$ ). The EDX data indicate that these precipitates are composed essentially of $\mathrm{Ca}$ and $\mathrm{P}$ with minor amounts of $\mathrm{Mg}$ (Figures $3 \mathrm{~d}$ and $\mathrm{f}$ ).

Under TEM (Figure 4), the amorphous nature of the mineral precipitates is clearly evidenced. They start to form as thin coatings defining the cell surfaces (Figure 4a), and evolve into globular precipitates attached to cell surfaces and within the bacterial organic film between cells (Figures $4 \mathrm{~b}$ and c). The globules have a diametre of few tens to few hundred nanometres, and show abundant electron-lucent centres resulting from devolatilization caused by electron-beam irradiation (Figure 4b). The cytoplasmic membrane is occasionally visualized when images are taken in under-focus conditions (Figure $4 \mathrm{~d}$, inset).

Analytical electron microscopy analyses of the mineralized clotty precipitates (Figure 4e) indicate that they are made of amorphous phases (Figure 4f) of $\mathrm{Ca}$ and $\mathrm{P}$ with minor amounts of $\mathrm{Mg}$ (Figures $4 \mathrm{~g}$ and $\mathrm{h}$ ). In the earliest stages of the culture (3-5 days), the amorphous precipitates were very rich in $\mathrm{Ca}$ and $\mathrm{P}$, and very poor in $\mathrm{Mg}$, with $\mathrm{Ca}: \mathrm{P}$ atomic proportions of around 5:6, whereas the same ratio of the natural apatite used as standard was 5:3. With increasing time, the amorphous precipitates progressively became poorer in $\mathrm{Ca}$ and richer in $\mathrm{Mg}$.

After 3 days of incubation, the C. marismortui cultures produced dumbbell-shaped, cross-shaped and spheroidal bioliths (Figures 5a-c) commonly surrounded and adhered to by organic gels (Figures $5 \mathrm{a}, \mathrm{b}$ and e). These bioliths sometimes preserved mineralized bacterial moulds (Figure 5d). The EDX spectra indicated that these bioliths were composed of $\mathrm{Ca}, \mathrm{C}$ and $\mathrm{O}$ with minor amounts of $\mathrm{P}$ and $\mathrm{Mg}$. The $P$ content clearly increased within the partially mineralized organic gel surrounding Ca-carbonate bioliths (compare EDX spectra in Figures 5a and e with those in Figures 5d and f).

Although XRD data indicate that the precipitates that formed during the first week of incubation were essentially amorphous, the morphological and textural features of dumbbells, crosses and spherulites observed under SEM indicate that these bioliths were protocrystalline precipitates. In addition, EDX data indicate that they were composed essentially of Ca-carbonate. A close examination of the bioliths, preferentially in rough surfaces, revealed the presence of broken moulds of mineralized cells defined by rounded to subangular Ca-carbonate nanoparticles embedded in organic films (Figure 5e). Such nanoparticles aggregated to form spiny biolith surfaces (Figure 5f), which, at the end of the experiments, evolved into fibrous aragonite spherulites (Figure 6a), occasionally with preserved bacterial moulds inside them (Figure 6b). The same 

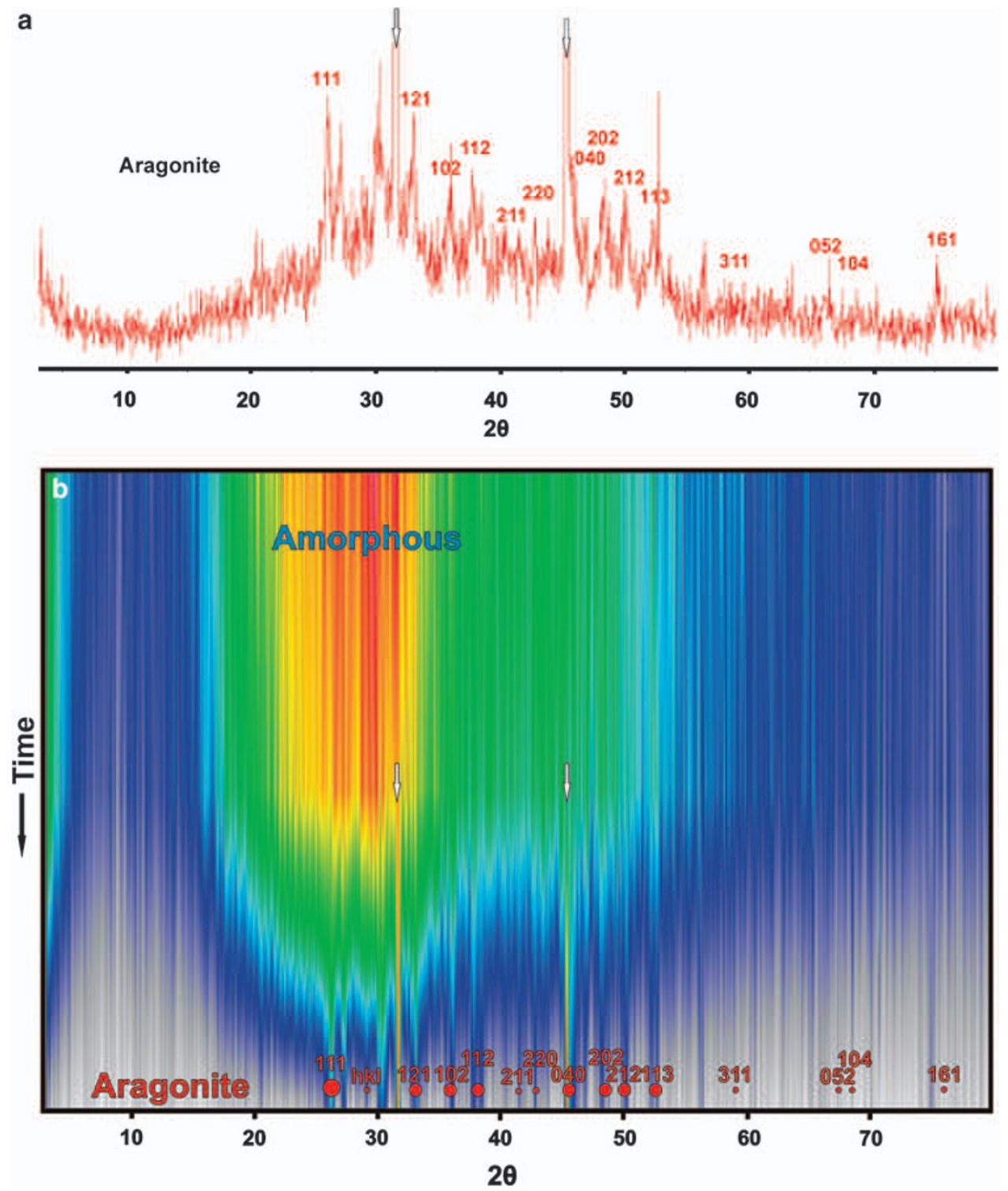

Figure 2 (a) X-ray diffraction (XRD) pattern of the mature precipitates composed of aragonite plus amorphous substances after 40 days of incubation. (b) Map drawn from XRD patterns, illustrating the transition from amorphous precipitates to aragonite with time. Colours in the map indicate the changing intensity of the diffracted X-rays as a function of $2 \theta$ and time of culture, with warmer colours for progressively higher intensities. Residues of halite of the culture media are also present in the patterns (white arrows).

nanoparticles and bacterial moulds, as those that were found in the bioliths formed during the first week of incubation, and that did not produce X-ray diffraction, were also visible on the surface of the mature aragonite bioliths (Figures $6 \mathrm{c}$ and $\mathrm{d}$ ).

In addition to aragonite, the precipitates that formed after 40 days of incubation also contained struvite crystals (Figure 7a) with abundant and wellpreserved mineralized bacteria on their surface (Figures 7b and c). Detailed SEM observation reveals that bacterial cells were also surrounded by aggregated globular nanoparticles, similar to those found in carbonate bioliths. Figure 7d shows one broken mineralized bacterium with two concentric layers, each formed by a double accumulation of globular nanoparticles. The EDX analyses of bacterial cell aggregates demonstrated that they were composed of $\mathrm{P}$ and $\mathrm{Ca}$ with minor amounts of $\mathrm{Mg}$ (Figure $7 \mathrm{~b}$ ).

Throughout incubation, bioliths of different sizes and maturation stages, and bacteria with different degrees of mineralization were commonly found. With increasing time, however, the number of bioliths increased, and their composition changed, from mainly amorphous phases of Ca phosphate and carbonate at the beginning of the experiments (3-7 days) to precipitates made essentially of aragonite and struvite at the end of the experiment.

\section{Discussion and conclusions}

The precipitation of ACP precursors for bacterial aragonite is here reported, to the best of our 


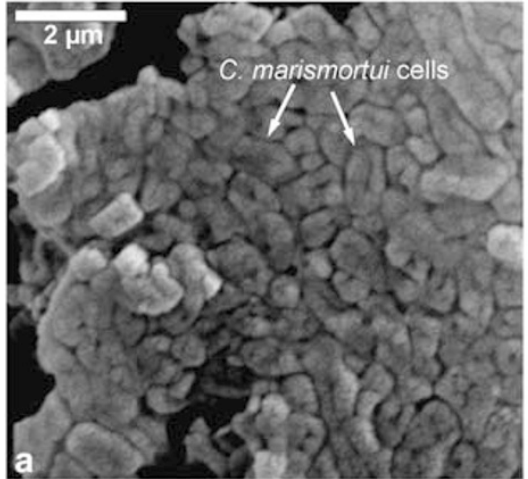

d
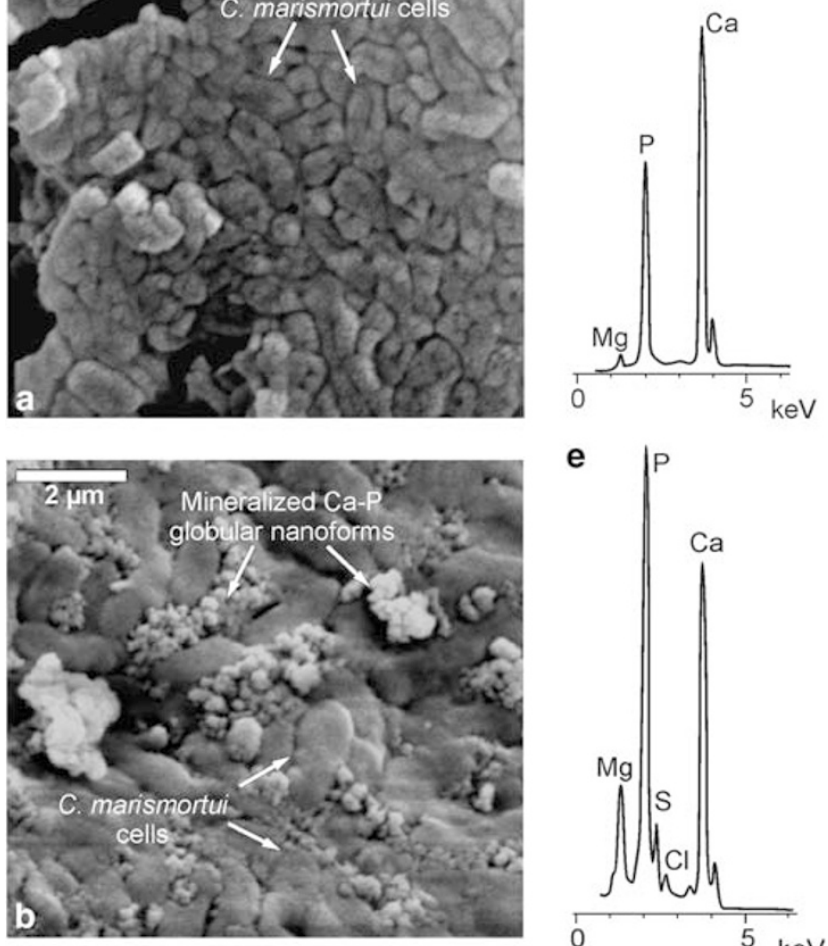

e
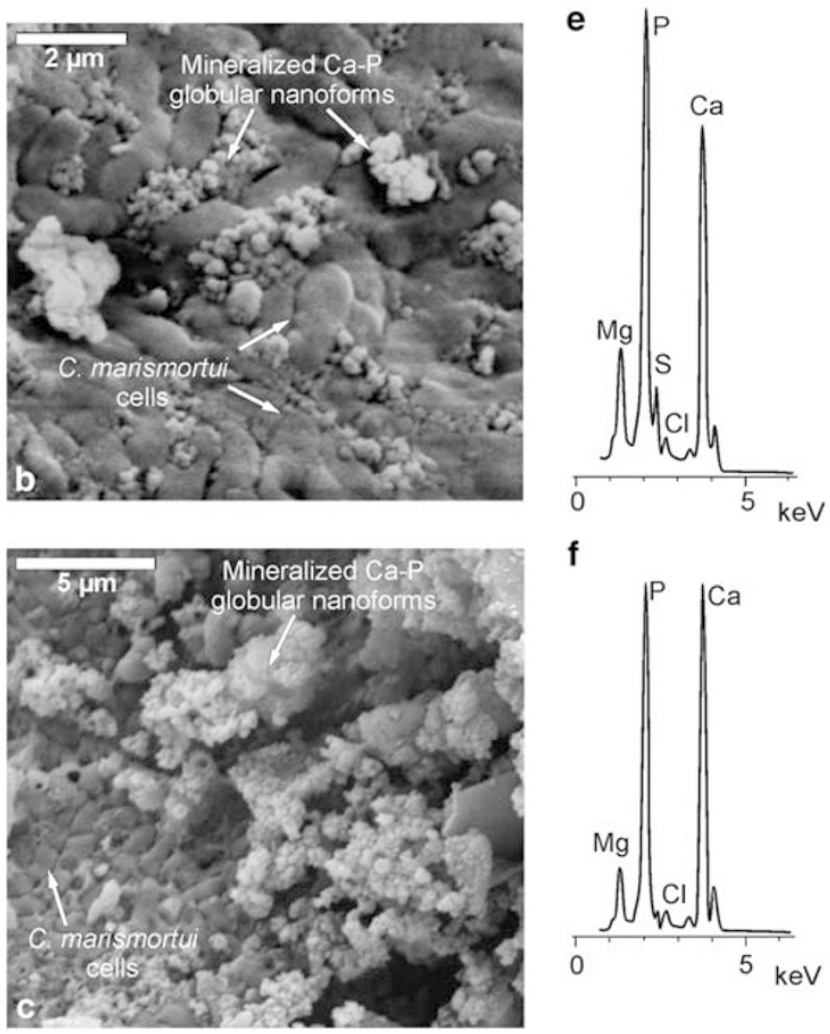

f

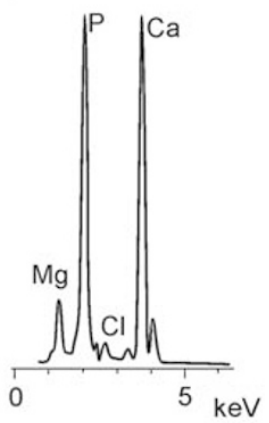

Figure 3 Scanning electron microscopy (SEM) images and energy dispersive X-ray (EDX) spectra of incipiently mineralized bacterial cells. (a) Mineralized bacteria after 4 days of incubation. (b) Same as (a), with globular nanoforms on bacterial surfaces. (c) Same as (a and b) after 6 days of incubation. (d, e and f) EDX spectra of mineralized organic films after 3 days (d) and 5 days of incubation (e and f).

knowledge, for the first time. The precipitation of the observed amorphous Ca-rich and P-rich globular phase with low Mg content occurred first, and persisted during crystal accretion in the incipiently mineralized areas around $C$. marismortui surfaces. This is confirmed by (1) the systematic presence of $\mathrm{P}$ in gel-rich areas full of Ca-carbonate nanoparticles in the crystallization front at the surface of aragonite bioliths throughout the experiment; and by (2) the existence of $\mathrm{Ca}$ in the mineralized bacterial aggregates resting on struvite crystals. The low $\mathrm{Mg}$ content of this amorphous Ca phosphate, despite the high Mg:Ca ratio in the medium (4:1), is explained by the fact that (1) $\mathrm{Mg}^{2+}$ ions tended to remain in the solution (where they are thought to be heavily solvated, according to de Leeuw and Parker (2001), due to strongly attractive $\mathrm{Mg}$-water interactions; (2) $\mathrm{Ca}^{2+}$ ions were actively excluded from all bacteria cells to maintain low concentrations of intracellular $\mathrm{Ca}^{2+}$, whereas $\mathrm{Mg}^{2+}$ ions were generally pumped towards the interior of the cells, as demonstrated by Rosen (1987); and (3) $\mathrm{Ca}^{2+}$ was selectively adsorbed onto the negatively charged bacterial cell surfaces according to Wolt (1994) and Maier et al. (2000).

The dissolution of the amorphous phosphate phase that formed on $C$. marismortui surfaces was followed by in situ precipitation of globular to subangular Ca-carbonate nanoparticles that attached to bacterial cell walls and gels related to them. The later aggregation of mineralized bacterial cells finally produced aragonite. Similar nanoparticles have also been found in other bacterial $\mathrm{Ca}-\mathrm{Mg}$ carbonate precipitates, called 'nanoglobules' (Aloisi et al., 2006; Sánchez-Román et al., 2008). SánchezNavas et al. (2009) have interpreted them as the nanocrystalline building units that form bacterially precipitated carbonate mesocrystals.

The precipitation of amorphous phosphate precursors has been reported also for bacterial biomineralization of apatite and iron oxides both in laboratory experiments and in the geological record (Krajewski et al., 1994; Sánchez-Navas et al., 1998; Martín-Algarra and Sánchez-Navas, 1995, 2000; Sánchez-Navas and Martín-Algarra, 2001; Miot et al., 2009). Biological material containing Cacarbonate (Addadi et al., 2003; Marxen et al., 2003) is also frequently formed through transitional and disordered amorphous Ca-carbonate phases (Politi et al., 2006). In fact, the initial formation of transient amorphous precursor phases that transform into more stable crystalline phases is a widespread trend in biomineralization (Weiner et al., 2005). Recent studies have reported precipitation by invertebrates of amorphous Ca carbonate precursors for aragonite and calcite (Raz et al., 2002), and that of 'aragonite-like' amorphous $\mathrm{CaCO}_{3}$ on cyanobacterial cell surfaces (Obst et al., 2009). Degradation of the bacterial organic compounds and of the associated amorphous precipitates is related to the formation of crystalline nanoparticles that have size equivalent to those found on $C$. marismortui surfaces, and that later accrete to form many Ca-Mg carbonate and phosphate biominerals (Aloisi et al., 2006; Benzerara et al., 2006; Rivadeneyra et al., 2006; Bontognali et al., 2008; Sánchez-Navas et al., 2009; Sánchez-Román et al., 2009a).

It is widely accepted that bacterial mineralization usually occurs on the wall or on the surface of the cells that are presumably encapsulated by 

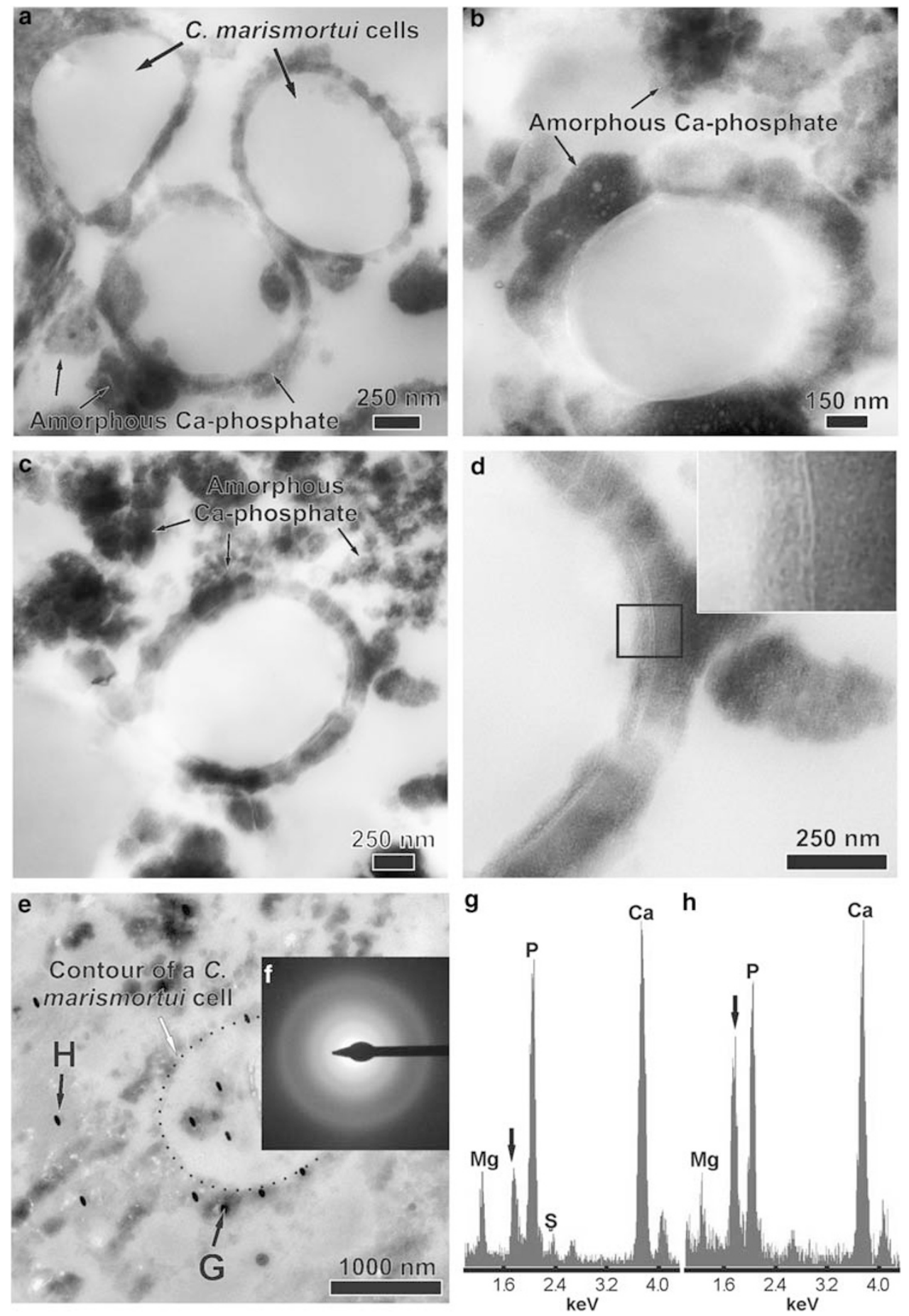

Figure 4 Transmission electron microscopy (TEM) images (a-d: performed in elastic scattering image (ESI) mode), selected-area electron diffraction (SAED) and analytical electron microscopy (AEM) analyses in scanning transmission electron microscopy (STEM) mode of amorphous calcium phosphate phases (dark areas) surrounding Chromohalobacter marismortui cells after 3 days of incubation. (a) Mineralized bacterial surfaces. Note the formation of clotty precipitates surrounding the bacteria and outside of the cell. (b) Globules of amorphous mineralized precipitates with electron-lucent centres within them. (c) Globular amorphous precipitates are abundant around mineralized bacteria. (d) Close-up of (c). Note the presence of globular amorphous phases on both sides around the cytoplasmic membrane (inset). (e) Location of single-spot analyses (dark ellipses; arrows point to the analyses reproduced in $\mathbf{g}$ and $\mathbf{h}$ ). (f) SAED pattern of the mineralized areas. (g) AEM analysis of a dark globule. (h) AEM analysis of a lighter, less mineralized area. Arrows in ( $\mathbf{g}$ and $\mathbf{h}$ ) point to the $\mathrm{SiK}_{\alpha}$ peak artefacts (see Materials and methods).

extracellular polysaccharides (Beveridge and Fyfe, 1985; Ferris et al., 1991; Rivadeneyra et al., 1998; Dupraz et al., 2004, Sánchez-Román et al., 2009a, among others). In the case studied, the surface of C. marismortui (a Gram-negative bacterium) provides sites for nucleation for Ca-phosphate after adsorbing 

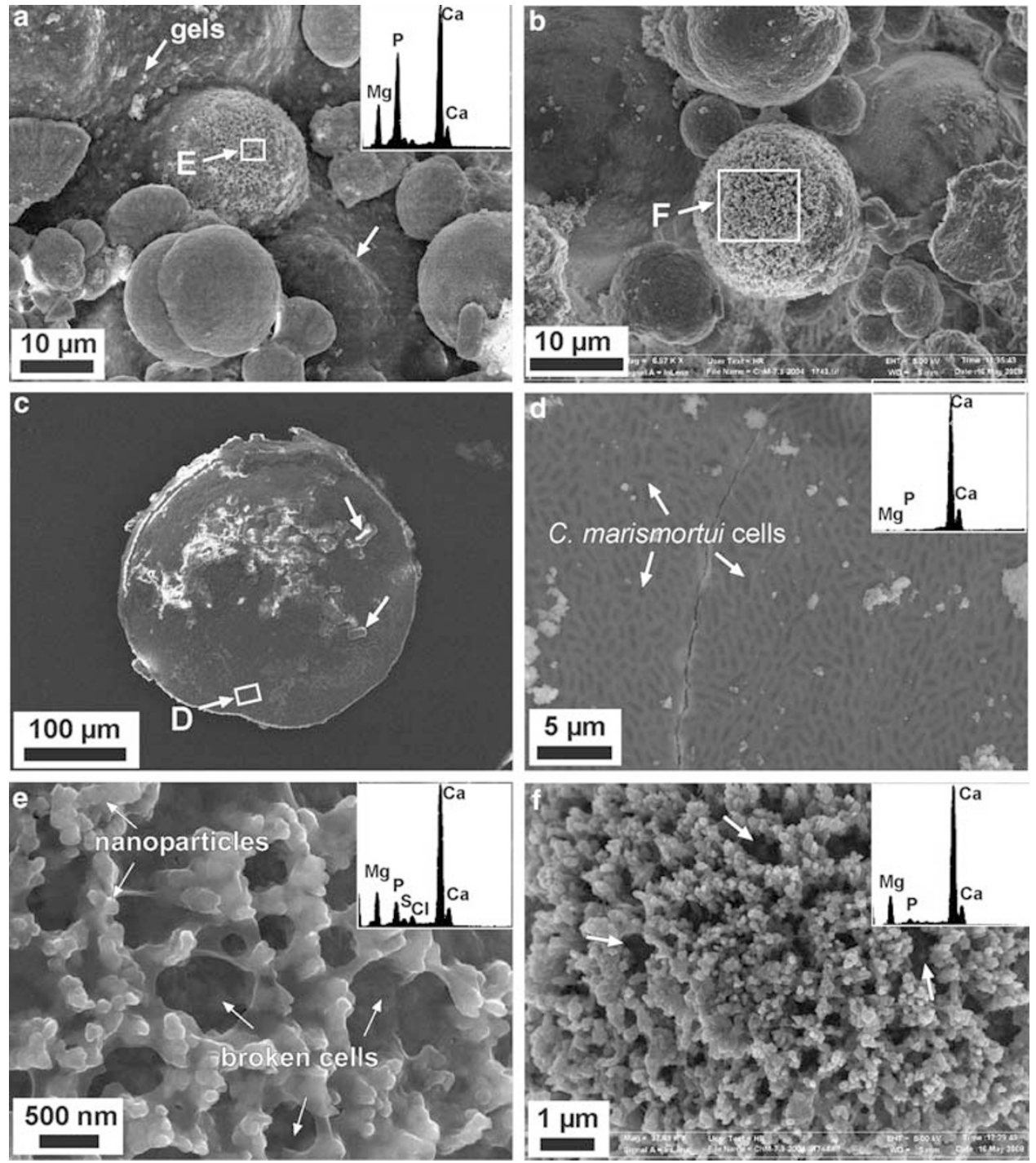

Figure 5 Scanning electron microscopy (SEM) images and energy dispersive X-ray (EDX) spectra of carbonate bioliths and associated gels formed during the first week of incubation. (a) Spherulites and dumbbells attached by gels. Arrows point to areas richer in gels. EDX spectrum of the gel-rich areas indicates that they are composed of $\mathrm{Ca}, \mathrm{Mg}$ and $\mathrm{P}$. (b) Same as (a): note the rough surface of bioliths in the areas poorer in gels. (c) View of the flat base of a spherulite, which was detached from the glass of the culture flask, with later accretion of dumbbells (arrows). (d) Close-up of the boxed area in (c), showing a dense aggregate of mineralized bacterial cells composed of Ca-carbonate (see EDX spectrum). (e) Close-up of the area boxed in (a). Note the abundance of Ca-carbonate nanoparticles delimiting the bacterial cell contours and embedded in a P- and Mg-rich organic film (see EDX spectrum). (f) Close-up of the area squared in (b), showing the spiny surface of a more mineralized spherulith formed by aggregation of the nanoparticles. Empty voids in Figures 5e and $\mathrm{f}$ (arrows) correspond to moulds of degraded bacteria.

$\mathrm{Ca}^{2+}, \mathrm{PO}_{4}^{3-}$ and some $\mathrm{Mg}^{2+}$, into cellular envelopes. Nucleation would start by binding $\mathrm{Ca}^{2+}$ to the phosphate groups of the cytoplasmic membrane and of the outer membrane (mainly phospholipids and lipopolysaccharides). This promotes the formation of transient ACP phases, with low Ca:P ratio in comparison to apatite and inorganically precipitated ACP. This indicates that, in this study, the ACPs bearing some $\mathrm{Mg}$ are Ca-rich organophosphorate compounds.

Bosak and Newman (2003) indicate that, in the Precambrian ( $>545$ million years ago), heterogeneous nucleation on bacterial surfaces may have exerted a stronger control on carbonate formation than does microbial metabolic activity. Martinez et al. (2008) have demonstrated that nucleation on bacterial cells depends on the surface charge, which is controlled both by structural features of cell membranes and by bacterial metabolism. Our data confirm that the formation of aragonite is controlled by (1) the $\mathrm{Ca}^{2+}$ concentration on the surface of living bacterial cells, driving the precipitation of Ca-rich phosphate precursors, and by (2) the bacterial metabolic activity. After initial bacterial emission of $\mathrm{CO}_{2}$, three chemical species form in water solution $\left(\mathrm{H}_{2} \mathrm{CO}_{3}, \mathrm{HCO}_{3}^{-}\right.$and $\left.\mathrm{CO}_{3}^{2-}\right)$, for 

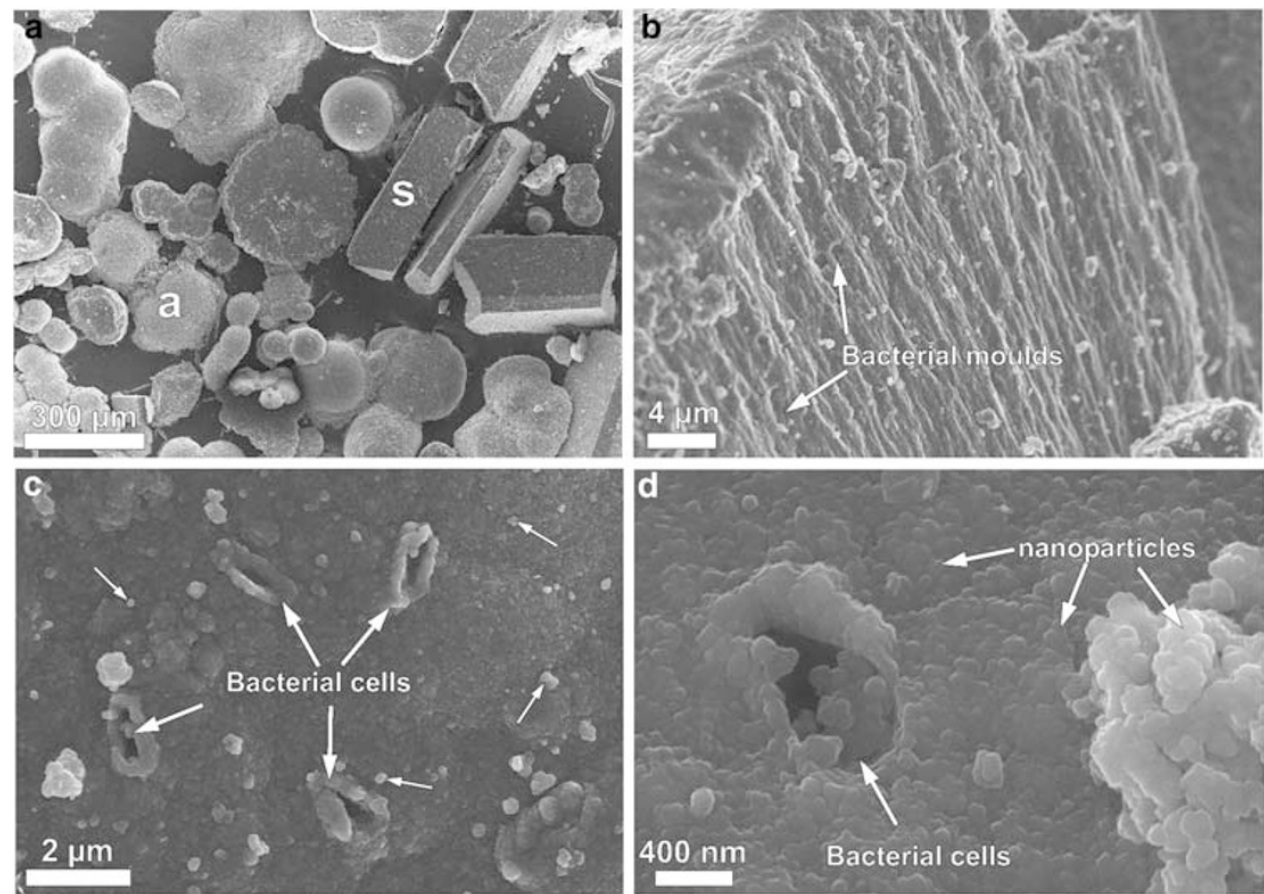

Figure 6 Scanning electron microscopy (SEM) images of aragonite precipitates by Chromohalobacter marismortui at the end of the experiment (40 days of incubation). (a) Struvite crystals (s) and aragonite bioliths with spiny surfaces (a). (b) Fibrous-radiated internal structure of a broken aragonite spherulite with mineralized bacteria. (c) Aragonite spherulite surface with mineralized bacteria and abundant crystalline nanoparticles (small arrows). (d) Under high magnification, both the surface of the aragonite spherulite and the bacterial mould is formed by aggregates of Ca-carbonate crystalline nanoparticles.
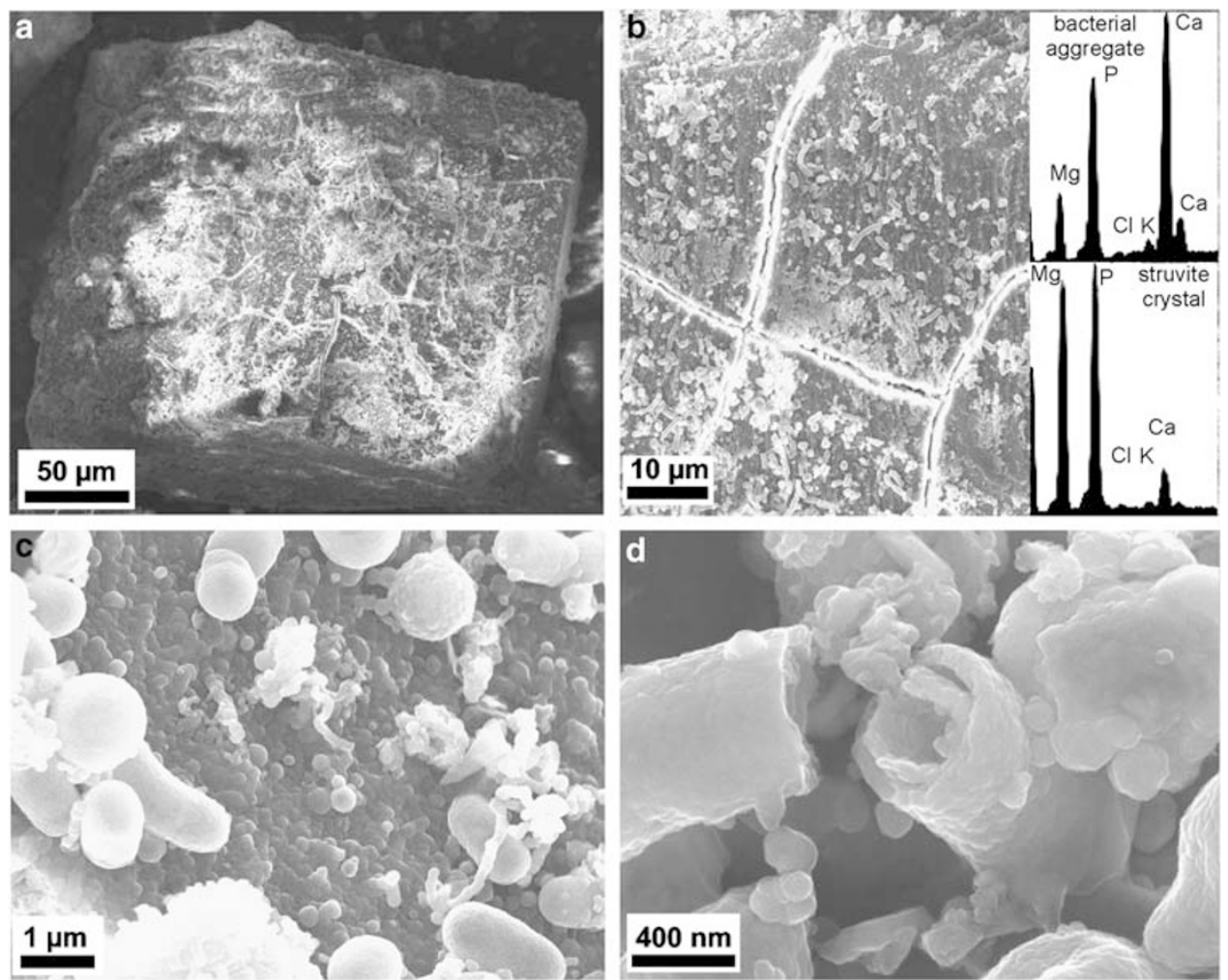

Figure 7 Scanning electron microscopy (SEM) images and energy dispersive X-ray (EDX) spectra of mineralized bacteria on the surface of a struvite crystal. (a) General view of a struvite crystal surface. (b) Close-up of (a) shows abundant mineralized bacteria on the surface of the crystal. EDX spectrum of bacterial aggregates display a marked peak in Ca level, which is absent in analyses of struvite-crystal surfaces. (c) Nanoparticles covering the bacterial-cell surfaces and the surface of the struvite crystal. (d) Detail of a cell with two concentric layers, each mineralized by a double set of globular nanoparticles. 
which the partitioning is governed by the $\mathrm{pH}$ (Capewell et al., 1998):

$$
\mathrm{CO}_{2}+\mathrm{H}_{2} \mathrm{O} \leftrightarrow \mathrm{H}_{2} \mathrm{CO}_{3} \leftrightarrow \mathrm{HCO}_{3}^{-}+\mathrm{H}^{+} \leftrightarrow 2 \mathrm{H}^{+}+\mathrm{CO}_{3}^{2-}
$$

Partitioning of $\mathrm{HCO}_{3}^{-}$and $\mathrm{CO}_{3}^{2-}$ in Ca-rich environments responsible of Ca carbonate supersaturation is explained by the reaction:

$$
\mathrm{CO}_{2}+\mathrm{H}_{2} \mathrm{O}+\mathrm{CaCO}_{3} \text { (solid) } \leftrightarrow 2 \mathrm{HCO}_{3}^{-}+\mathrm{Ca}^{2+}
$$

Reactions (1) and (2) clearly show that, as it is well known in natural (for example, karstic) aquatic environments, the increase in $\mathrm{CO}_{2}$ level promotes dissolution of $\mathrm{Ca}$ carbonates to form soluble $\mathrm{Ca}$ bicarbonate. Nonetheless, the precipitation of $\mathrm{Ca}$ carbonate (aragonite) from $\mathrm{CO}_{2}$-rich solutions in the presence of $\mathrm{Ca}^{2+}$ is promoted by the greater concentration of the $\mathrm{CO}_{3}^{2-}$ with respect to $\mathrm{HCO}_{3}^{-}$ and $\mathrm{H}_{2} \mathrm{CO}_{3}$ chemical species at alkaline $\mathrm{pH}$ values (Capewell et al., 1998). The Ca source used in this study is $\mathrm{Ca}$ acetate that is oxidized by aerobic bacteria according to the reaction:

$$
2 \mathrm{Ca}\left(\mathrm{CH}_{3} \mathrm{COO}\right)_{2}+7 \mathrm{O}_{2} \rightarrow 8 \mathrm{CO}_{2}+6 \mathrm{H}_{2} \mathrm{O}+2 \mathrm{Ca}^{2+}
$$

The precipitation of $\mathrm{CaCO}_{3}$ may have arisen from diverse causes: a common precipitation mechanism (for example, karstic environments) is $\mathrm{CO}_{2}$ outgassing and $\mathrm{H}_{2} \mathrm{O}$ evaporation. In addition to outgassing that accounts in the open system bacterial culture medium studied here, the alkalinization necessary for $\mathrm{CaCO}_{3}$ precipitation is also promoted by the presence of chemical species that could act as proton sinks. These are $\mathrm{PO}_{4}^{3-}$ and $\mathrm{NH}_{3}$ that are present in the culture medium due to metabolic degradation of peptone and yeast extract; peptone and yeast extract are the main nutrients for bacterial growth. Nevertheless, glucose is used first, and its rapid consumption promotes initial bacterial growth providing the energy needed to hydrolyse proteins and abundant $\mathrm{CO}_{2}$, according to the reaction:

$$
\mathrm{C}_{6} \mathrm{H}_{12} \mathrm{O}_{6}+6 \mathrm{O}_{2} \rightarrow 6 \mathrm{CO}_{2}+6 \mathrm{H}_{2} \mathrm{O}
$$

The rapid and early $\mathrm{CO}_{2}$ emission due to degradation of glucose, peptone and yeast extract makes the $\mathrm{pH}$ drop initially. Nevertheless, as the medium contains a large quantity of amino acids, the alkalinization is later induced due to $\mathrm{CO}_{2}$ outgassing and $\mathrm{NH}_{3}$ production. This allows us to explain the observed increase of $\mathrm{pH}$ from 7.2 to $\sim 9$. Although it is not possible to make a precise mass balance because the commercial proteose peptone and yeast extract do not have an exact chemical formula, if the complete aerobic oxidation of amino acids, for example, serine is considered, an alkaline medium rich in ammonia can be produced:

$$
\mathrm{C}_{3} \mathrm{O}_{3} \mathrm{H}_{7} \mathrm{~N}+2.5 \mathrm{O}_{2} \rightarrow 3 \mathrm{CO}_{2}+2 \mathrm{H}_{2} \mathrm{O}+\mathrm{NH}_{3}
$$

Besides $\mathrm{CO}_{2}$ and $\mathrm{NH}_{3}$, degradation of the organic nutrients also provides abundant $\mathrm{PO}_{4}^{3-}$ ions that concentrate first around bacterial cells. Phosphate ions and, especially, ammonia are also hydrolysed in the same way as $\mathrm{CO}_{2}$ but, in this case, it favours $\mathrm{pH}$ rise according to the following reactions $(\mathrm{Wu}$ and Bishop, 2004):

$$
\begin{gathered}
\mathrm{NH}_{3}+\mathrm{H}_{2} \mathrm{O} \rightarrow \mathrm{NH}_{4}^{+}+\mathrm{OH}^{-} \\
\mathrm{PO}_{4}^{3-}+\mathrm{H}_{2} \mathrm{O} \rightarrow \mathrm{HPO}_{4}^{2-}+\mathrm{OH}^{-} \\
\mathrm{HPO}_{4}^{2-}+\mathrm{H}_{2} \mathrm{O} \rightarrow \mathrm{H}_{2} \mathrm{PO}_{4}^{-}+\mathrm{OH}^{-}
\end{gathered}
$$

The role of the reaction (6) in the alkalinization must be more important than that of the other two reactions, because nitrogen is more abundant than phosphorous in the culture medium. Consequently, after the initial $\mathrm{CO}_{2}$ emission and $\mathrm{pH}$ drop, carbonate precipitation could start as soon as $\mathrm{pH}$ rises nearly to 8 (after 3 days of incubation). Excess of $\mathrm{PO}_{4}^{3-}$ around bacterial cells provides attachment sites for $\mathrm{Ca}^{2+}$, in addition to those available from phospholipids of the cytoplasmic and outer bacterial membranes, allowing amorphous $\mathrm{Ca}$ phosphate supersaturation, and its kinetically favoured precipitation close to bacterial surfaces. Therefore, $\mathrm{NH}_{3}$ and $\mathrm{PO}_{4}^{3-}$ act as proton sinks, and their protonation promoted both alkalinization and conversion of $\mathrm{CO}_{2}$ into $\mathrm{CO}_{3}^{2-}$. In addition, the dissolution of the amorphous Ca phosphate also promotes alkalinization. As the stoichiometry of the commonly observed and inorganically precipitated amorphous Ca phosphates is $\mathrm{Ca}_{9}\left(\mathrm{PO}_{4}\right)_{6}$ (Betts and Posner, 1974; Posner et al., 1984), a simplified equation for the amorphous Ca phosphate dissolution is:

$$
\mathrm{Ca}_{9}\left(\mathrm{PO}_{4}\right)_{6}+12 \mathrm{H}_{2} \mathrm{O} \rightarrow 9 \mathrm{Ca}^{2+}+6 \mathrm{H}_{2} \mathrm{PO}_{4}^{-}+12 \mathrm{OH}^{-}
$$

When $\mathrm{pH}$ increases up to around 9, all hydrolytic reactions mentioned above reach the equilibrium and, therefore, stop progressively. With time, the $\mathrm{pH}$ rise and the increase in $\mathrm{CO}_{3}^{2-}, \mathrm{NH}_{4}^{+}$and $\mathrm{PO}_{4}^{3-}$ favour $\mathrm{CaCO}_{3}$ and struvite precipitation. In addition, solvated $\mathrm{Mg}^{2+}$ ions promote the dissolution of the early amorphous $\mathrm{Ca}$ phosphate, releasing $\mathrm{Ca}^{2+}$ that can be used for aragonite precipitation. The precipitation of stable crystal structures (aragonite and struvite) may result from the interaction between electronegative cations $\left(\mathrm{Ca}^{2+}\right.$ ions that act as a soft acid) and electropositive anions (or molecular groups that act as soft base: $\mathrm{CO}_{3}^{2-}$ ), and between electropositive cations (which act as hard acids: $\mathrm{NH}_{4}^{+}, 6 \mathrm{H}_{2} \mathrm{O} \cdot \mathrm{Mg}^{2+}$ ) and electronegative anions (which act as hard bases: $\mathrm{PO}_{4}^{3-}$ ). Here, according to Pearson's ideas of hard and soft acids and bases (Pearson, 1966; Burdett and McLarnan, 1984), the driving force for (hard-soft) + (soft-hard) $\rightarrow$ (hardhard) + (soft-soft) is the stronger bond interaction between $\mathrm{Ca}^{2+}$ and $\mathrm{CO}_{3}^{2-}$ in the aragonite structure, rather than any type of van der Waals interaction between the $\mathrm{NH}_{4}^{+}, 6 \mathrm{H}_{2} \mathrm{O} \cdot \mathrm{Mg}^{2+}$ and $\mathrm{PO}_{4}^{3+}$ molecular groups in the struvite structure.

Similar metabolic pathways have been proposed for the precipitation of Ca- and/or Mg-carbonates by 
other halophilic aerobic bacteria (for example, Rivadeneyra et al., 2004; Sánchez-Román et al., 2008), but such mechanisms have never shown the formation of an ACP precursor for carbonates. Owing to the similarity of external cell envelopes and metabolic activity between $C$. marismortui and other halophilic aerobic bacteria, a potential exists for ACPs to be precursor phases for carbonate minerals precipitated by other bacteria. Clarification of how these amorphous phases are formed and stabilized may have broader implications on understanding the origin of early life in the biogeological record. In conclusion, this experimental study also provides potential biosignatures that may be useful to test Earth surface and extraterrestrial habitats for the presence and the biomineralization activity of bacteria similar to $C$. marismortui.

\section{Acknowledgements}

We thank M del Mar Abad, A González, I Guerra and M J Martínez, from the CIC-University of Granada, for their help during SEM and TEM research. We also thank Prof A Matilla (Dept of Inorganic Chemistry, University of Granada) for his help in reviewing the chemistry-related portion of this paper. We also appreciate the helpful comments of the editor Prof G Kowalchuk and of three anonymous reviewers, and thank D Nessbitt for his revision of the English text. This study was supported by funds from the project CGL2009-09249 (Spanish Ministry of Education and Science), and by Groups RNM 208, 179 and 270 (Junta de Andalucía).

\section{References}

Abad MM, Nieto F. (2006). Quantitative EDX Analysis in TEM. Practical Development, Limitations and Standards. In: Méndez-Vilas A (ed). Science, Technology and Education of Microscopy: an Overview. pp 687694 FORMATEX Microscopy Book Series. http:// www.formatex.org/microscopy1/78.pdf.

Addadi L, Raz S, Weiner S. (2003). Taking advantage of disorder: amorphous calcium carbonate and its roles in biomineralization. Ad Mater 15: 959-970.

Allen CC, Albert FG, Chafetz HS, Combie J, Graham CR, Kieft TL et al. (2000). Microscopic physical biomarkers in carbonate hot springs: implications in the search for life on Mars. Icarus 147: 49-67.

Aloisi G, Gloter A, Krüger M, Wallman K, Guyot F, Zuddas P. (2006). Nucleation of calcium carbonate on bacterial nanoglobules. Geology 34: 1017-1020.

Beavon J, Heatley NG. (1962). The occurrence of struvite (magnesium ammonium phosphate hexahydrate) in microbial cultures. J Gen Microbiol 31: 167-169.

Benzerara K, Menguy N, López-García P, Yoon T, Kazmierczak J, Tyliszczak T et al. (2006). Nanoscale detection of organic signatures in carbonate microbiolites. Proc Natl Acad Sci USA 103: 9440-9445.

Betts F, Posner AS. (1974). A structural model for amorphous calcium phosphate. Trans Am Cryst Assoc 10: $73-84$.
Beveridge TJ, Fyfe WS. (1985). Metal fixation by bacterial cell walls. Can J Earth Sci 22: 1893-1898.

Bontognali TRR, Vasconcelos C, Warthmann R, Dupraz C, Bernasconi SM, McKenzie JA. (2008). Microbes produce nanobacteria-like structures, avoiding cell entombment. Geology 36: 663-666.

Bosak T, Newman DK. (2003). Microbial nucleation of calcium carbonate in the Precambrian. Geology 31: 577-580.

Burdett JK, McLarnan TJ. (1984). An orbital interpretation of Pauling's rules. Am Mineral 69: 601-621.

Capewell SG, Hefter G, May PM. (1998). Potentiometric investigation of the weak association of sodium and carbonate ions at $25^{\circ} \mathrm{C}$. J Sol Chem 27: 865-877.

Castanier S, Le Métayer-Levrel G, Perthuisot JP. (1999). Ca-carbonate precipitation and limestone genesis-the microbiologist point of view. Sed Geol 126: 9-23.

de Leeuw NH, Parker SC. (2001). Surface-water interactions in the dolomite problem. Phys Chem Chem Phys 3: 3217-3221.

Dupraz C, Visscher PT, Baumgartner LK, Reid RP. (2004). Microbe-mineral interactions: early carbonate precipitation in a hypersaline lake (Eleuthera Island, Bahamas). Sedimentology 51: 745-765.

Ehrlich HL. (2002). Geomicrobiology (4th edn) Marcel Dekker: New York, p 768 .

Ferris FG, Fyfe WS, Beveridge TJ. (1991). Bacteria as nucleation sites for authigenic minerals. Diversity of Environmental Biogeochemistry. In: Berthelin J (ed). Dev Geochem. Elsevier: Amsterdam, pp 319-326.

Krajewski KP, Van Capellen P, Trichet J, Kuhn O, Lucas O, Martín-Algarra A et al. (1994). Biological processes and apatite formation in sedimentary environments. Ecl Geol Helv 87: 701-745.

Maier RM, Pepper IL, Gerba ChP. (2000). Environ Microbiol. Academic Press: San Diego, CA.

Martín JD. (2004). Using XPowder-a sofware package for powder X-ray diffraction analysis. D.L.GR-1001/04, ISBN: 84-609-1497-6, Spain. http://www.xpowder.com/.

Martín-Algarra A, Sánchez-Navas A. (1995). Phosphate stromatolites from condensed cephalopod limestones, Upper Jurassic, Southern Spain. Sedimentology 42: 893-919.

Martín-Algarra A, Sanchez-Navas A. (2000). Bacterially mediated authigenesis in Mesozoic stromatolites from condensed pelagic sediments (Betic Cordillera, Southern Spain). In: Glenn CR, Lucas J, Prévôt-Lucas L (eds). Marine Authigenesis: From global to microbial 499-525.

Martinez RE, Pokrovsky OS, Schott J, Oelkers EH. (2008). Surface charge and zeta-potential of metabolically active and dead cyanobacteria. J Colloid Interface Sci 323: 317-325.

Marxen JC, Becker W, Finke D, Hasse B, Epple M. (2003). Early mineralization in Biomphalaria glabrata: Microscopic and structural results. J Mollusc Stud 69: 113-121.

Miot J, Benzerara K, Morin G, Kappler A, Bernard S, Obst $\mathrm{M}$ et al. (2009). Iron biomineralization by anaerobic neutrophilic iron-oxidizing bacteria. Geochim Cosmochim Acta 73: 696-711.

Morita RY. (1980). Calcite precipitation by marine bacteria. Geomicrobiol J 2: 63-82.

McKay DS, Thomas-Keptra KL, Romanek CS, Gibson Jr EK, Vali H. (1996). Evaluating the evidence for past life on Mars. Science 274: 2123-2124.

Obst M, Dynes JJ, Lawrence JR, Swerhone GDW, Benzerara K, Karunakaran C et al. (2009). Precipitation 
of amorphous $\mathrm{CaCO}_{3}$ (aragonite-like) by cyanobacteria: A STXM study of the influence of EPS on the nucleation process. Geochim Cosmochim Acta 73: 4180-4198.

Pearson RG. (1966). Acids and bases. Science 151: 172-177.

Politi Y, Levi-Kalisman Y, Raf S, Wilt F, Addadi L, Weiner S et al. (2006). Structural characterization of transient amorphous calcium carbonate precursor phase in sea urchin embryos. Adv Funct Mater 16: 1289-1298.

Posner AS, Blumenthal NC, Betts F. (1984). Chemistry and structure of precipitated hydroxyapatites. In: Nriagu JO, Moore PB (eds). Phosphate Minerals. Springer: Berlin, pp. 330-350.

Raz S, Testeniere O, Hecker A, Weiner S, Luquet G. (2002). Stable amorphous calcium carbonate is the main component of the calcium storage structures of Crustacean Orchesia cavimana. Biol Bull 203: 269-274.

Rivadeneyra MA, Ramos-Cormenzana A, Delgado G, Delgado R. (1996). Process of carbonate precipitation by Deleya halophila. Curr Microbiol 32: 308-313.

Rivadeneyra MA, Delgado G, Ramos-Cormenzana A, Delgado R. (1998). Biomineralization of carbonates by Halomonas eurihalina in solid and liquid media with different salinities: crystal formation sequence. Res Microbiol 149: 277-286.

Rivadeneyra MA, Delgado G, Soriano M, RamosCormenzana A, Delgado R. (1999). Biomineralization of carbonates by Marinococcus albus and Marinococcus halophilus isolated from the Salar de Atacama (Chile). Curr Microbiol 39: 53-57.

Rivadeneyra MA, Delgado G, Soriano M, Ramos-Cormenzana A, Delgado R. (2000). Precipitation of carbonates by Nesterenkonia halobia in liquid media. Chemosphere 41: 617-624.

Rivadeneyra MA, Párraga J, Delgado R, Ramos-Cormenzana A, Delgado G. (2004). Biomineralization of carbonates by Halobacillus trueperi in solid and liquid media with different salinities. FEMS Microbiol Ecol 48: 39-46.

Rivadeneyra MA, Martín-Algarra A, Sánchez-Navas A, Martín-Ramos D. (2006). Carbonate and phosphate precipitation by Chromohalobacter marismortui. Geomicrobiol J 23: 89-101.

Rosen BP. (1987). Bacterial calcium transport. Biochem Biophys Acta 906: 101-110.

Sánchez-Navas A, Martín-Algarra A. (2001). Genesis of apatite in phosphate stromatolites. Eur J Mineral 13: 361-376.

Sánchez-Navas A, Martín-Algarra A, Nieto F. (1998). Bacterially-mediated authigenesis of clays in phosphate stromatolites. Sedimentology 45: 519-533.

Sánchez-Navas A, Martín-Algarra A, Rivadeneyra MA, Melchor S, Martín-Ramos JD. (2009). Crystal-growh behaviour $\mathrm{Ca}-\mathrm{Mg}$ carbonate bacterial spherulites. Cryst Growth Des 9: 2690-2699.
Sánchez-Román M, Rivadeneyra MA, Vasconcelos C, McKenzie JA. (2007). Biomineralization of carbonate and phosphate by halophilic bacteria: influence of $\mathrm{Ca}^{2+}$ and $\mathrm{Mg}^{2+}$ ions. FEMS Microbiol Ecol 61: 273-281.

Sánchez-Román M, Vasconcelos C, Schmid T, Dittrich M, McKenzie JA, Zenobi R et al. (2008). Aerobic microbial dolomite at the nanometer scale: implications for the geologic record. Geology 36: 879-882.

Sánchez-Román M, Vasconcelos C, Warthmann R, Rivadeneyra MA, McKenzie JA. (2009a). Microbial dolomite precipitation under aerobic conditions: results from Brejo do Espinho Lagoon (Brazil) and culture experiments. IAS Spec Publ 41: 167-178.

Sánchez-Román M, McKenzie JA, de Luca Rebello W, Rivadeneyra MA, Vasconcelos C. (2009b). Presence of sulfate does not inhibit low-temperature dolomite precipitation. Earth Planet Sci Lett 285: 131-139.

Vali H, Koster HM. 1986. Expanding behavior, structural disorder, regular and random irregular interstratification of 2-1 layer-silicates studied by high-resolution images of transmission electron-microscopy. Clay Miner 21: 827-859.

van Lith Y, Vasconcelos C, Warthmann R, Martins JCF, McKenzie JA. (2002). Bacterial sulfate reduction and salinity: two controls on dolomite precipitation in Lagoa Vermelha and Brejo do Espinho (Brazil). Hydrobiologia 485: 35-49.

van Lith Y, Warthmann R, Vasconcelos C, McKenzie JA. (2003). Sulphate-reducing bacteria induce lowtemperature dolomite and high Mg-calcite formation. Geobiology 1: 71-79.

Vasconcelos C, McKenzie JA. (1997). Microbial mediation of modern dolomite precipitation and diagenesis under anoxic conditions (Lagoa Vermelha, Rio de Janeiro, Brazil). J Sed Res 67: 378-390.

Ventosa A, Gutierrez MC, García MT, Ruiz-Berraquero F. (1989). Classification of 'Chomobacterium marismortui' in a new genus, Chromohalobacter gen. nov., as Chromohalobacter marismortui comb. nov., nom. rev. Inter J System Bacteriol 39: 382-385.

Warthmann R, van Lith Y, Vasconcelos C, McKenzie JA, Karpoff AM. (2000). Bacterially induced dolomite precipitation in anoxic culture experiments. Geology 28: 1091-1094.

Weiner S, Sagi I, Addadi L. (2005). Choosen the crystallization path less traveled. Science 309: 1027-1028.

Wolt JD. (1994). Soil Solution Chemistry: Applications to Environmental Science and Agriculture. Wiley: New York, USA.

Wu Q, Bishop PL. (2004). Enhancing stuvite crystallization from anaerobic supernatant. J Environ Eng Sci 3: 21-29.

Wright DT, Wacey D. (2005). Precipitation of dolomite using sulfate-reducing bacteria from the Coorong Region, South Australia: significance and implications. Sedimentology 52: 987-1008. 